\title{
COMPARATIVE ANALYSIS USES WEIGHTED PRODUCT (WP) AND SIMPLE ADDITIVE WEIGHTING (SAW) METHODS IN THE BEST GRADUATION SELECTION SYSTEM
}

\author{
Agus Sidiq Purnomo') dan Anief Fauzan Rozi ${ }^{\text {) }}$ \\ ${ }^{1}$ Teknik Informatika, Fakultas Teknologi Informasi, Universitas Mercu Buana Yogyakarta \\ ${ }^{2}$ Sistem Informasi, Fakultas Teknologi Informasi, Universitas Mercu Buana Yogyakarta \\ 1,2 Jl. Jembatan Merah No. 84 C Gejayan Yogyakarta \\ E-mail : sidiq@mercubuana-yogya.ac.id ${ }^{1)}$, anief@mercubuana-yogya.ac.id ${ }^{2)}$
}

\begin{abstract}
Determination of students in the Study Program of the Information System of Mercu Buana University in Yogyakarta is still in the process of the decision. This is because it has not maximized the use of technology to use existing data in decision making. This assessment uses 6 criteria that are used as parameters in conducting experiments, in order to make the right decisions in this study, namely Multiple Attribute Decision Making(MADM) Simple Additive Weighting (SAW) and Weighted Product (WP). Based on the data that has been tested using the system, the system can be used properly by ranking results based on the highest value. The test results for the speed of access time obtained values of 1362.90 ms for SAW and $672.60 \mathrm{~ms}$ for WP. While the test results using Relative Standard Deviation (RSD) obtained a value of 8,2004 for SAW and $10.1868 \%$ for WP. In this case using the WP method is more because it is more optimal.
\end{abstract}

Keywords: Decision Support System, Best Graduate Students, WP, SAW, RSD

\section{PENDAHULUAN}

Penentuan mahasiswa lulusan terbaik pada Proram Studi Sistem Informasi Universitas Mercu Buana Yogyakarta sampai saat ini masih mengalami kendala pada proses hasil pengambilan keputusan. Hal ini dikarenakan belum dimaksimalkan penggunaan teknologi untuk pemanfaatan data yang ada dalam pengambilan keputusan.

Dalam penentuan mahasiswa lulusan terbaik biasanya hanya diputuskan secara sepihak dengan salah satu kriteria yaitu IPK dan mengabaikan kriteria yang lainnya untuk mempercepat pemilihan. Padahal selain IPK masih ada kriteria-kriteria lain yang sudah ditetapkan sebagai acuan acuan seperti : (1) Jenis Mahasiswa, (2) Ketepatan Lulusan, (3) IPK, (4) Usia, (5) Prestasi Akademik dan Non Akademik. Hal ini disebabkan belum ada sistem khusus yang menangani permasalahan ini.

Penelitian ini bertujuan untuk untuk : (1) Menghasilkan model sistem pendukung keputusan untuk pemilihan mahasiswa lulusan terbaik sesuai dengan datadata akademik yang sudah tersedia secara otomatis, (2) Mengetahui metode yang lebih optimal yang dapat diterapkan dalam pemilihan mahasiswa lulusan terbaik.

Manfaat dari penelitian ini, antara lain : (1) Diharapkan model yang dihasilkan dapat digunakan oleh staff tata usaha program studi sebagai alat bantu dalam menentukan mahasiswa lulusan terbaik, sehingga lebih cepat dan akurat, (2) Model yang dihasilkan dapat memberikan gambaran mengenai metode yang lebih optimal yang dapat diterapkan dalam penentuan mahasiswa lulusan terbaik.

\section{RUANG LINGKUP}

Dalam penelitian ini permasalahan mencakup:

1. Bagaimana menerapkan metode MADM SAW dan WP pada sistem pendukung keputusan untuk pemilihan mahasiswa lulusan terbaik berdasarkan proses bisnis yang sudah berjalan, data akademik, dan trasnkip nilai akhir mahasiswa

2. Metode yang digunakan program studi (universitas) saat ini masih belum optimal.

\section{BAHAN DAN METODE}

Berikut dipaparkan kajian empiris, kajian teori dan metode yang digunakan dalam penelitian ini.

\subsection{Kajian Empiris}

Beberapa penelilian yang terkait dalam penelitian ini antara lain seperti penelitian mengenai lulusan terbaik dengan menggunakan SAW (Simple Additive Weighting), dan dilanjutkan dengan penelitian serupa menggunakan WP (Weighted Product) dengan studi kasus di Fakultas Teknik Universitas Muhammadiyah Purwokerto, kriteria yang digunakan dalam penelitian ini ada 4 kriteria, yaitu : Indeks Prestasi Kumulatif (IPK), Masa Studi (dalam bulan), Tidak ada nilai D, dan Nilai C maksimal 1. Pengujian dilakukan dengan 10 mahasiswa dengan nilai tertinggi 7,714 (SAW) dan 0.174 (WP) (Wijaya \& Mustafidah, 2015) (Yoni \& Mustafidah, 2016).

Selanjutnya penelitian serupa yang dengan SAW digunakan untuk menentukan dosen terbaik dengan studi kasus di STMIK Global Tangerang, menggunakan 3 kriteria penilaian yaitu : kualitas pengajaran, 
kedisiplinan, penilaian teman sejawat. Pengujian dilakukan dengan 4 dosen, hasil yang diperoleh adalah perangkingan berdasarkan nilai tertinggi (Rini, dkk., 2015).

Selanjutnya penelitian dengan SAW yaitu Penentuan Anak Asuh Pena Prestasi Pada Lembaga Amil Zakat Dana Peduli Ummat, menggunakan 4 kriteria penilaian yaitu : Penghasilan Orang Tua, Pekerjaan Orang Tua, Usia Orang Tua, dan Jumlah Saudara. Hasil dari penelitian menunjukkan bahwa sistem tidak dapat berjalan efektif jika nilai maksimal dari atribut benefit atau nilai minimal dari cost berupa angka 0 (nol) (Lailiyah, dkk., 2016).

Selanjutnya penelitian dengan WP yaitu penentuan pegawai terbaik yang menggunakan 4 kriteria penilaian yaitu : kehadiran, kecepatan kerja, tanggung jawab, dan kerja sama. Hasil perhitungan tertinggi dengan sistem maupun secara manual yaitu 0.0782, sehingga dapat disimpulkan bahwa kedua perhitungan serupa (Septian \& Purnomo, 2017).

Selanjutnya penelitian mengenai perbandingan SAW dan WP dengan studi kasus rekrutmen pegawai di PT. Warta Media Nusantara, dalam penelian ini komparasi kedua metode didapatkan dari waktu proses yang menghasikan SAW sebagai metode yang dipilih (Setyawan, dkk., 2017).

Selanjutnya penelitian mengenai penentuan siswa lulusan terbaik dengan metode promethee di SMA Negeri 3 Pontianak, dengan 4 kriteria penilaian yaitu : nilai Rapor, nilai UAS, nilai UN, dan prestasi. Hasil dari penelitian ini adalah perangkingan berdasarkan kriteria yang ditetapkan sebagai dasar penilaian dan perbandingan dengan perhitungan manual (Bajandoh \& Hidayati, 2018).

\subsection{Sistem Pendukung Keputusan}

Sistem pendukung keputusan (SPK) biasanya dibangun untuk mendukung solusi atas suatu masalah atau untuk mengevaluasi suatu peluang atau sering juga disebut sebagai aplikasi SPK. Aplikasi SPK biasanya menggunakan CBIS (Computer Based Information System) yang fleksibel, interaktif, dan dapat diadaptasi, yang dikembangkan untuk mendukung solusi atas masalah manajemen spesifik yang tidak terstruktur (Kusrini, 2007).

Ada beberapa metode yang dapat digunakan untuk menyelesaikan masalah MADM antara lain, (a) Simple Additive Weighting (SAW), (b) Weighted Product (WP), (c) ELimination Et Choix TRaduisant la realiE (ELECTRE), (d) Tecniques for Order Preference by Similary to Ideal Solution (TOPSIS), dan (e) Analitic Hierarchy Process (AHP) (Kusumadewi, dkk., 2006).

\subsection{Weighted Product (WP)}

Langkah-langkah penyelesaianya adalah WP, antara lain seperti berikut (Kusumadewi, dkk., 2006):

1. Menggunakan perkalian untuk menghubungkan rating atribut.

2. Rating setiap atribut harus dipangkatkan dulu dengan bobot atribut yang bersangkutan.
3. Dilakukan perbaikan bobot (W), sehingga menghasilkan bobot baru (W baru), seperti pada Persamaan (1).

$$
W_{j}=\frac{W_{j}}{\sum W_{j}}
$$

4. Mencari vektor $\mathrm{S}$ dan dilanjut mencari vektor $\mathrm{V}$ yang digunakan untuk perangkingan. Metode WP menggunakan perkalian untuk menghubungkan rating atribut, dimana rating setiap atribut harus dipangkatkan dulu dengan bobot atribut yang bersangkutan. Proses ini sama halnya dengan proses normalisasi. Preferensi untuk alternatif Ai diberikan seperti pada Persamaan (2)

$$
S_{i}=\prod_{j=1}^{n} X_{i j j}^{w_{i j}}
$$

Dimana $\sum w j=w j$ adalah pangkat bernilai positif untuk atribut keuntungan, dan bernilai negatif untuk atribut biaya. Sedangkan preferensi relatif dari setiap alternatif, diberikan seperti pada Persamaan (3)

$$
V_{i}=\frac{\prod_{j=1}^{\mathrm{n}} X_{\mathrm{i} j}^{w_{i j}}}{\prod_{j=1}^{\mathrm{n}}\left(X_{j}^{*}\right)^{w_{j}}}
$$

5. Hasil akhir perolehan dari proses perangkingan yaitu menghasilkan nilai terbesar sehingga diperoleh nilai terbesar yang dipilih sebagai altematif terbaik (Ai) sebagai solusi.

\subsection{Simple Additive Weighting (SAW)}

Langkah-lalngkah penyelesaian dalam metode SAW, antara lain sebagai berikut (Kusumadewi, dkk., 2006):

1. Menetukan kriteria-kriteria yang akan dijadikan acuan dalam pengambilan keputusan, yaitu $\mathrm{Ci}$.

2. Menentukan ranting kecocokan setiap alternatif pada setiap kriteria.

3. Membuat matriks keputusan berdasarkan kritria $\left(\mathrm{C}_{\mathrm{i}}\right)$, kemudian melakukan normalisasi matrik berdasarkan persamaan yang disesuaikan dengan jenis attribut sehingga diperoleh matriks ternormalisasi R.

4. Proses normalisasi dapat dilihat pada Persamaan (4).

$$
r_{\mathrm{i} j}=\left\{\begin{array}{l}
\frac{X_{\mathrm{i} j}}{\operatorname{Max} X_{\mathrm{i} j}} \\
i \\
\frac{\operatorname{Min} X_{\mathrm{i} j}}{X_{\mathrm{i} j}}
\end{array}\right.
$$

Dimana $r_{i j}$ adalah rating kinerja ternormalisasi dari alternatif $A_{i}$ pada atribut $C_{j} ; I=1,2, \ldots \ldots, m$ dan $j$ $=1,2, \ldots \ldots \ldots, \mathrm{n}$.

5. Hari akhir perolehan dari proses perangkingan yaitu penjumlahan dari perkalian matriks ternormalisasi $\mathrm{R}$ dengan vektor bobot sehingga diperoleh nilai 
terbesar yang dipilih sebagai alternatif terbaik $\left(\mathrm{A}_{\mathrm{i}}\right)$, seperti pada Persamaan (5)

$$
V_{i}=\sum_{j=1}^{n} w_{j} r_{i j}
$$

Dimana $\mathrm{V}_{\mathrm{i}}$ adalah rangking untuk setiap alternatif, $\mathrm{W}_{\mathrm{j}}$ adalah nilai bobot dari setiap kriteria, $\mathrm{r}_{\mathrm{ij}}$ adalah nilai rating kinerja ternormalisasi, dan Nilai $\mathrm{V}_{\mathrm{i}}$ yang lebih besar mengindikasikan bahwa alternatif $\mathrm{A}_{\mathrm{i}}$ lebih terpilih.

\subsection{Skala Likert}

Skala likert merupakan skala yang digunakan untuk mengukur sikap, pendapat dan persepsi seseorang atau sekelompok orang tentang fenomena sosial (Sugiyono, 2014).

Dengan skala likert, maka kriteria/variabel yang akan diukur akan dijabarkan menjadi indikator variabel dan dijadikan sebagai titik tolak ukur dalam menyusun itemitem instrumen yang berupa pertanyaan atau pernyataan.

\subsection{Relative Standard Deviation (RSD)}

Berdasarkan hasil perangkingan yang telah diperoleh menggunakan FMADM, selanjutnya hasil tersebut dapat diujikan dengan menggunakan Relative Standard Deviation (RSD), seperti pada Persamaan (6) (Savitha \& Chandrasekar, 2011).

$$
R S D=\frac{S}{\bar{x}} \times 100 \%
$$

RSD dinyatakan dalam persen dan diperoleh dengan mengalikan standar deviasi (S) dengan 100 dan membagi produk ini dengan rata-rata $\bar{x}$ (Savitha and Chandrasekar 2011).

\subsection{Metode Penelitian}

Data yang digunakan dalam penelitian ini adalah data mahasiswa lulusan pada yudisium periode mei 2018 dari Program Studi Sistem Informasi Universitas Mercu Buana Yogyakarta periode dan data-data lain yang mendukung penelitian.

Contoh data penelitian yang digunakan sebagai data uji antara lain dapat dilihat pada Tabel 1.

\begin{tabular}{|c|c|c|c|c|c|c|c|c|}
\hline No & NIM & Nama & $\begin{array}{c}\text { Transfer/ } \\
\text { Baru }\end{array}$ & $\begin{array}{c}\text { Lama } \\
\text { Studi } \\
\text { (Th) }\end{array}$ & IPK & Usia & $\begin{array}{c}\text { Prestasi } \\
\text { Akademik }\end{array}$ & $\begin{array}{c}\text { Prestasi } \\
\text { Non } \\
\text { Akademik }\end{array}$ \\
\hline 1 & 14121001 & Andi Hidayatullah & Baru & 3.9 & 3.50 & 31.8 & Internasional & Tidak Ada \\
\hline 2 & 14121003 & Nurul Auliah & Baru & 3.9 & 3.77 & 22.5 & Tidak Ada & Tidak Ada \\
\hline 3 & 14121004 & Adito Efri & Baru & 3.9 & 3.33 & 26.6 & Tidak Ada & Tidak Ada \\
\hline 4 & 14121005 & Erwin Febrian & Baru & 3.9 & 3.53 & 28.5 & Tidak Ada & Tidak Ada \\
\hline 5 & 14121010 & Rahardian P.B & Baru & 3.9 & 3.67 & 23.2 & Tidak Ada & Tidak Ada \\
\hline 6 & 14121012 & Jefrei Labudo & Baru & 3.9 & 3.44 & 22.6 & Provinsi & Tidak Ada \\
\hline 7 & 14121017 & Rahmat Dwi Saputra & Baru & 3.9 & 3.55 & 22.4 & Tidak Ada & Tidak Ada \\
\hline 8 & 14121021 & Adi Sudewo & Baru & 3.9 & 3.88 & 22.8 & Tidak Ada & Tidak Ada \\
\hline 9 & 14121022 & Ricky Arif Sukoco & Baru & 3.9 & 3.95 & 22.8 & Tidak Ada & Tidak Ada \\
\hline 10 & 14121024 & Eko Darma Satrio & Baru & 3.9 & 3.77 & 23.5 & Tidak Ada & Tidak Ada \\
\hline 11 & 14121023 & Joko Purnomo & Baru & 3.9 & 3.68 & 22.4 & Tidak Ada & Tidak Ada \\
\hline 12 & 14121025 & Alfiatun Suhada & Baru & 3.9 & 3.83 & 23.3 & Tidak Ada & Tidak Ada \\
\hline 13 & 14121026 & Zidni Karimatan Nisa' & Baru & 3.9 & 3.60 & 22.8 & Tidak Ada & Tidak Ada \\
\hline 14 & 14121045 & Faizal Syahr Qomarudin & Baru & 3.9 & 3.75 & 21.8 & Tidak Ada & Tidak Ada \\
\hline 15 & 14121049 & Adrianus Nolapali & Baru & 3.9 & 3.29 & 24.6 & Tidak Ada & Tidak Ada \\
\hline
\end{tabular}

Tabel 1. Data Mahasiswa Lulusan

Metode penelitian yang digunakan dalam penelitian ini, secara garis besar dibagi menjadi 4 tahap, yaitu : (1) Inteligensi, (2) Desain, (3) Pemilihan, dan (4)
Implementasi dan solusi. Selanjutnya metode penelitian dapat dilihat pada Gambar 1 (Turban, dkk., 2005).

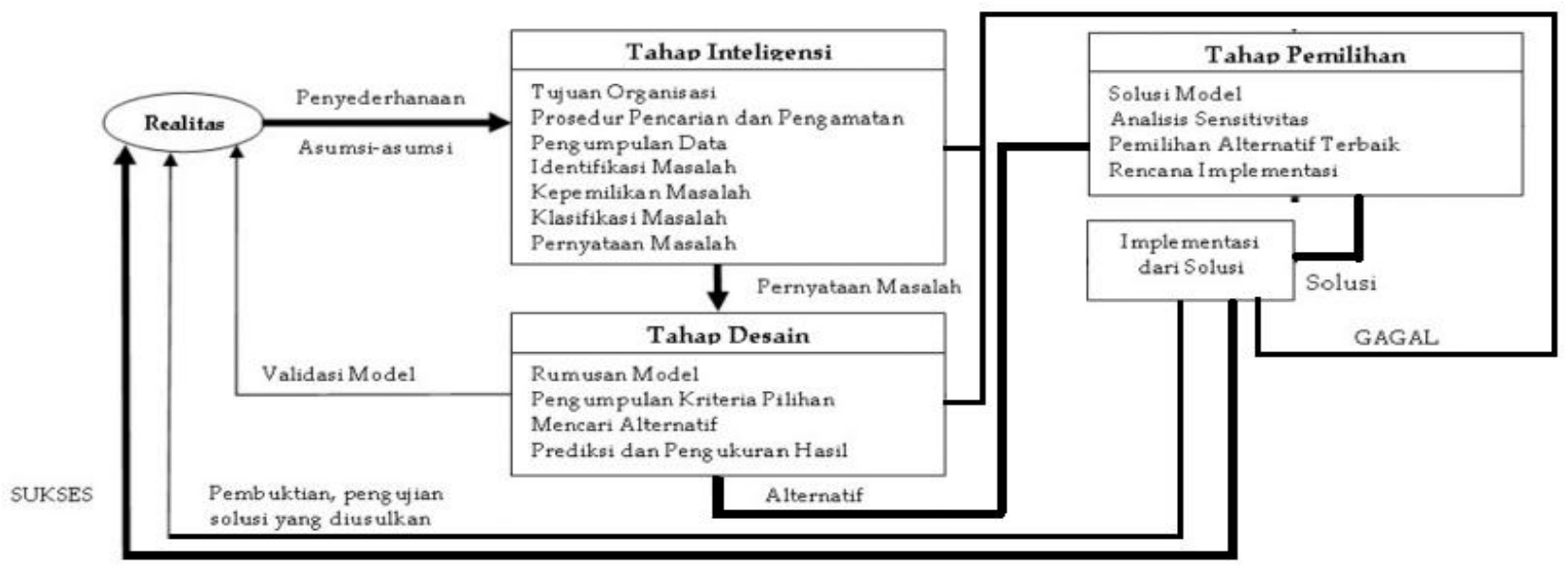

Gambar 1. Metode Penelitian 


\section{Inteligensi}

Dalam penelitian teknik pengumpulan data merupakan faktor terpenting demi keberhasilan penelitian sebagai bahan untuk melakukan analisis terhadap proses bisnis yang ada, yaitu : (a) Wawancara, (b) Studi Kepustakaan.

\section{Inteligensi}

Berdasarkan permasalahan yang telah diuraikan dalam tahap intelegensi, maka dibutuhkan sebuah sistem yang dapat membantu pemilihan lulusan terbaik berdasarkan kriteria-kriteria yang telah ditentukan. Dalam penyelesaian kasus tersebut berikut langkah yang harus dilakukan :

1) Menentukan kriteria yang digunakan untuk acuan pengambilan keputusan, yaitu : $\mathrm{C} 1=$ Jenis Mahasiswa, C2 = Ketepatan Lulusan, C3 = IPK, C4 = Usia, C5 = Prestasi Akademik, C6 = Prestasi Non Akademik.

2) Berikut standar penilaian dengan menggunakan skala likert dari masing-masing kriteria penilaian yang digunakan dalam sistem, seperti pada Tabel 2 .

Tabel 2. Kriteria Penilaian Berdasarkan Tingkat Kepentingan

\begin{tabular}{cccccc}
\hline Kriteria & \multicolumn{5}{c}{ Kepentingan } \\
\cline { 2 - 6 } & SK & K & C & B & SB \\
\hline C1 & Transfer & & & & Baru \\
C2 & & $<=3,24$ & $3,7-5$ th & $4,1-4,6$ th & $3,3-4$ th \\
C3 & & $>24$ th & $23,1-24$ th & $22,1-23$ th & $>3,75$ \\
C4 & & Kabupaten/Daerah & Provinsi & Nasional & Internasional \\
C5 & Tidak Ada & Kabupaten/Daerah & Provinsi & Nasional & Internasional \\
C6 & Tidak Ada & Kananana
\end{tabular}

Penyusunan tingkat kepentingan menggunakan skala likert. Dalam penelitian ini, skor yang diberikan untuk skala likert dapat dilihat pada Tabel 3.

Tabel 3. Skala likert

\begin{tabular}{lcl}
\hline Item & Keterangan & Skor \\
\hline SK & Sangat Kurang & 1 \\
K & Kurang & 2 \\
C & Cukup & 3 \\
B & Baik & 4 \\
SB & Sangat Baik & 5 \\
\hline
\end{tabular}

\section{Pemilihan}

Pilihan merupakan tindakan pengambilan keputusan yang kritis. Fase pilihan adalah fase dimana dibuat suatu keputusan yang nyata dan diambil suatu komitmen untuk mengikuti suatu tindakan tertentu.
Dalam tahap pemilihan ini akan dilakukan langkah ketiga dari penyelesaian dengan metode MADM dengan metode :

1) WP, yaitu membuat matriks keputusasn berdasarkan kriteria, selanjutnya menghitung bobot $\mathrm{W}$ baru, selanjutnya normalisasi vektor $\mathrm{S}$ berdasarkan bobot $\mathrm{W}$ baru, kemudian perangkingan $\mathrm{V}$ berdasarkan vektor $\mathrm{S}$.

2) SAW, yaitu membuat matriks keputusan berdasarkan kriteria, selanjutnya melakukan normalisasi matriks berdasarkan persamaan yang disesuaikan dengan jenis atribut sehingga diperoleh matriks ternormalisasi $\mathrm{R}$, kemudian perangkingan $\mathrm{V}$ dengan mengalikan matriks $\mathrm{R}$ dan bobot $\mathrm{W}$.

\section{Implementasi dan Solusi}

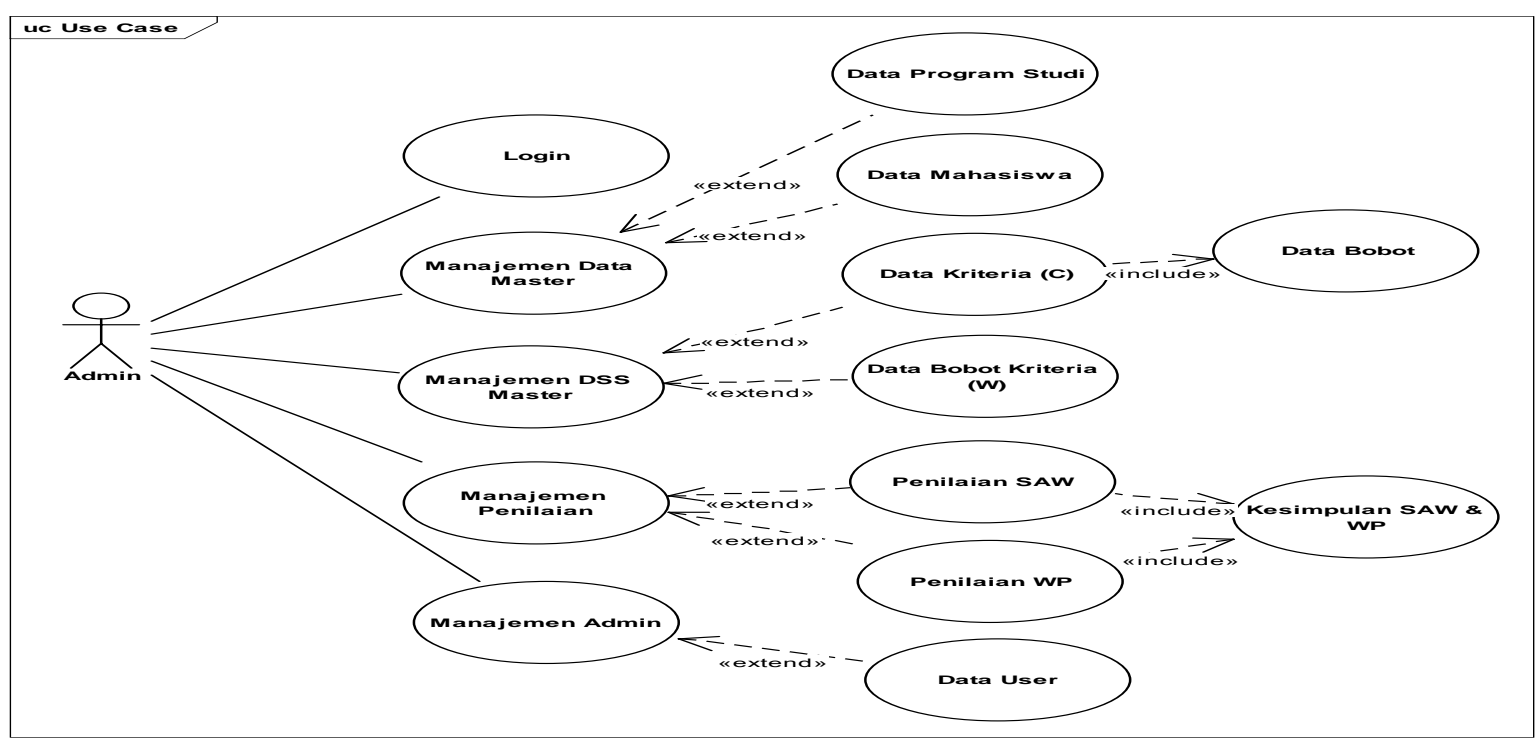

Gambar 2. Use Case Diagram 
UML (Unified Modeling Language) adalah bahasa yang telah menjadi standar dalam industri untuk visualisasi, merancang dan mendokumentasikan sistem piranti lunak.

Use Case Diagram ini menggambarkan fungsi dari sebuah sistem, dan interaksi yang dilakukan oleh aktor dengan sistem. Use Case Diagram dalam penelitian ini dapat dilihat pada Gambar 2.
Flowchart untuk melakukan perhitungan SAW dan WP dalam penelitian ini, dapat dilihat pada Gambar 3 .

Relasi tabel dalam penelitian ini, dapat dilihat pada Gambar 4. Tanda area garis putus-putus adalah tabel relasi untuk SAW, sedangan garis double adalah untuk WP.

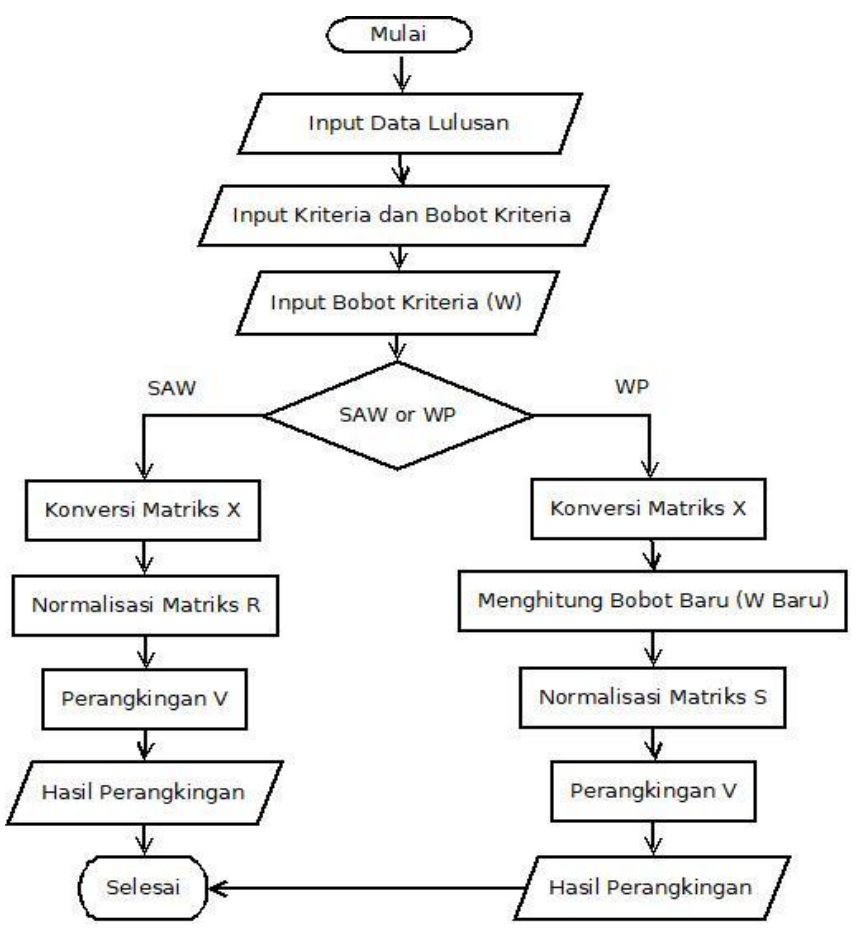

Gambar 3. Flowchart SAW dan WP

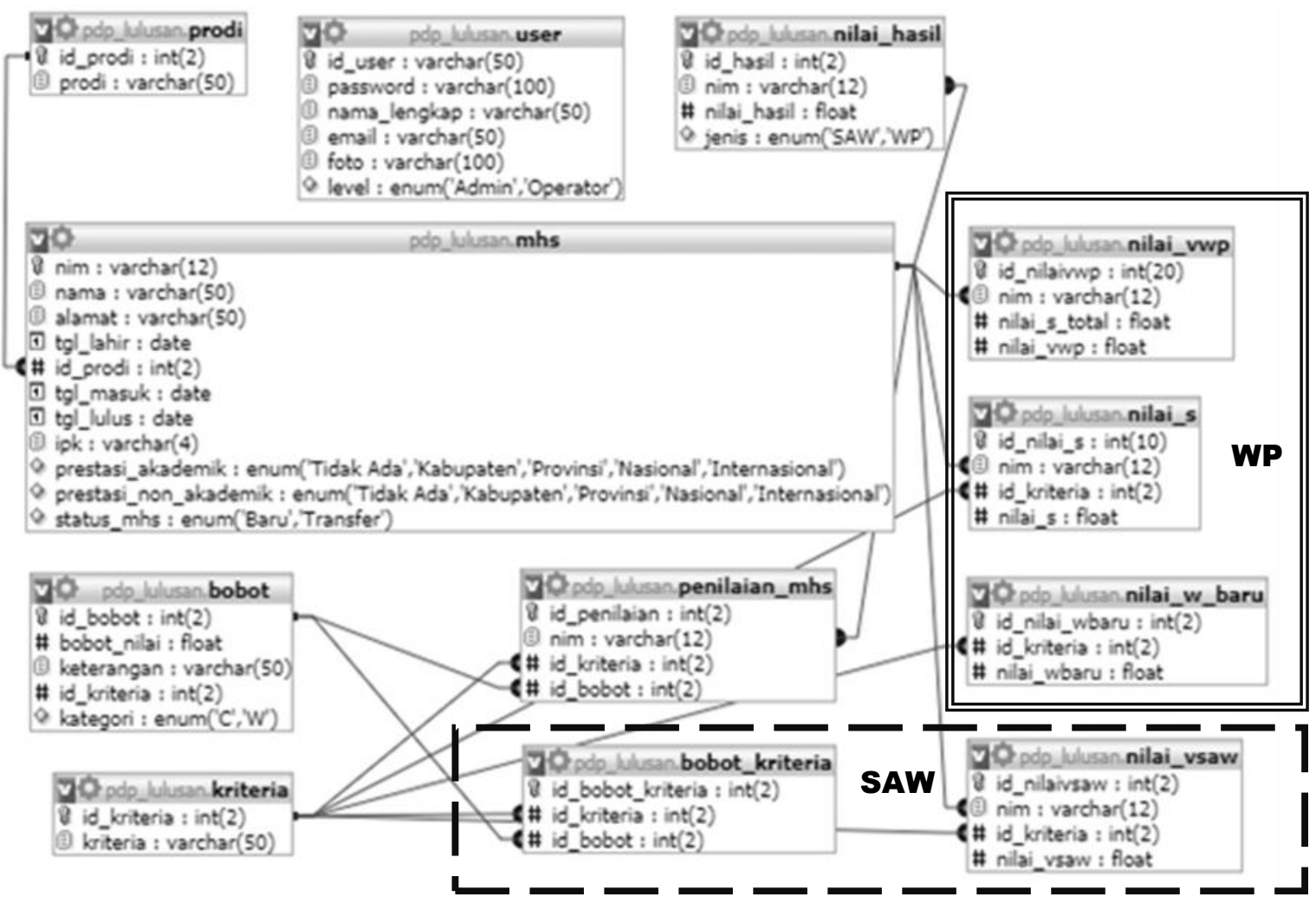

Gambar 4. Desain Relasi Database 


\section{PEMBAHASAN}

Dalam hal ini, pengambil keputusan memberikan kriteria (W), berdasarkan tingkat kepentingan masing-masing kriteria yang dibutuhkan seperti terlihat pada Gambar 5.

\begin{tabular}{|c|c|c|c|c|c|c|c|c|c|c|c|c|c|}
\hline \multicolumn{9}{|c|}{ Bobot Kriteria (W) } & \multicolumn{5}{|c|}{ Sudah Ada Data (6 Kriteria) } \\
\hline Show & $10 V$ & entries & & & & & \multicolumn{7}{|c|}{ Search: } \\
\hline & IE & ID Kriteria & $\downarrow \uparrow$ & Nama Kriteria & $\downarrow \uparrow$ & Bobot Nilai & $\downarrow \uparrow$ & Keterangan & & $\downarrow \uparrow$ & Aks & & $\downarrow \uparrow$ \\
\hline 1 & & $\mathrm{C} 1$ & & Transfer/Baru & & 2 & & Sangat Baik & & & & $\sqrt{6}$ & \\
\hline 2 & & $\mathrm{C} 2$ & & Ketepatan Waktu Lulusan & & 3 & & Baik & & & & $\sqrt{6}$ & \\
\hline 3 & & $\mathrm{C} 3$ & & IPK & & 4 & & Sangat Baik & & & & {$[8$} & \\
\hline 4 & & $\mathrm{C} 4$ & & Usia & & 2 & & Cukup & & & & $\sqrt{6}$ & \\
\hline 5 & & $\mathrm{C} 5$ & & Prestasi Akademik & & 2 & & Kurang & & & & {$[8$} & \\
\hline 6 & & $\mathrm{C} 6$ & & Prestasi Non Akademik & & 2 & & Kurang & & & & $\sqrt{6}$ & \\
\hline \multicolumn{9}{|c|}{ Showing 1 to 6 of 6 entries } & \multicolumn{3}{|c|}{ Previous } & 1 & Next \\
\hline
\end{tabular}

\section{Gambar 5. Penentuan Bobot Kriteria (W)}

\subsection{Hasil SAW dan WP}

Proses terakhir yaitu melakukan akumulasi terhadap jumlah nilai per masing-masing alternatif terhadap kriteria pada matriks V pada SAW dan WP, sehingga diperoleh hasil nilai akhir sebagai dasar untuk melakukan perangkingan. Seperti terlihat pada Gambar 6. Hasil secara keseluhan baik menggunakan metode SAW dan WP dapat dilihat pada Tabel 4 dan pada Gambar 7.

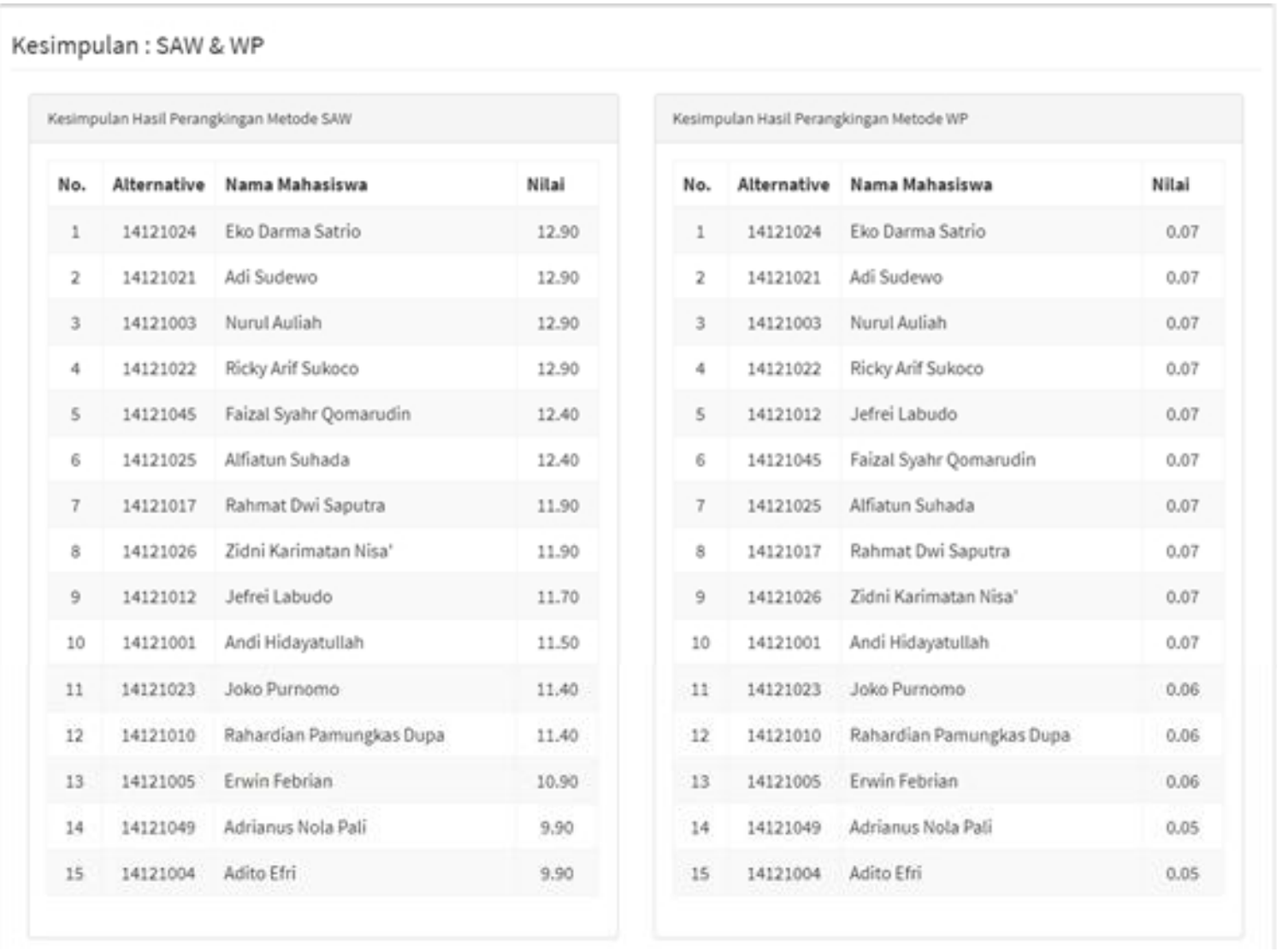

Gambar 6. Perangkingan SAW dan WP 
Tabel 4. Hasil SAW dan WP

\begin{tabular}{ccrrrr}
\hline \multirow{2}{*}{ Alternative } & \multirow{2}{*}{ Nama Mahasiswa } & \multicolumn{2}{c}{ Hasil SAW } & \multicolumn{2}{c}{ Hasil WP } \\
\cline { 3 - 5 } & Nilai & Peringkat & Nilai & Peringkat \\
\hline A1 & Eko Darma Satrio & 12.90 & 1 & 0.07 & 1 \\
A2 & Adi Sudewo & 12.90 & 2 & 0.07 & 2 \\
A3 & Nurul Auliah & 12.90 & 3 & 0.07 & 3 \\
A4 & Ricky Arif Sukoco & 12.90 & 4 & 0.07 & 4 \\
A5 & Faizal Syahr Qomarudin & 12.40 & 5 & 0.07 & 6 \\
A6 & Alfiatun Suhada & 12.40 & 6 & 0.07 & 7 \\
A7 & Rahmat Dwi Saputra & 11.90 & 7 & 0.07 & 8 \\
A8 & Zidni Karimatan Nisa' & 11.90 & 8 & 0.07 & 9 \\
A9 & Jefrei Labudo & 11.70 & 9 & 0.07 & 5 \\
A10 & Andi Hidayatullah & 11.50 & 10 & 0.07 & 10 \\
A11 & Joko Purnomo & 11.40 & 11 & 0.06 & 11 \\
A12 & Rahardian Pamungkas Dupa & 11.40 & 12 & 0.06 & 12 \\
A13 & Erwin Febrian & 10.90 & 13 & 0.06 & 13 \\
A14 & Adrianus Nola Pali & 9.90 & 14 & 0.05 & 14 \\
A15 & Adito Efri & 9.90 & 15 & 0.05 & 15 \\
\hline
\end{tabular}

\section{HASIL SAW DAN WP}

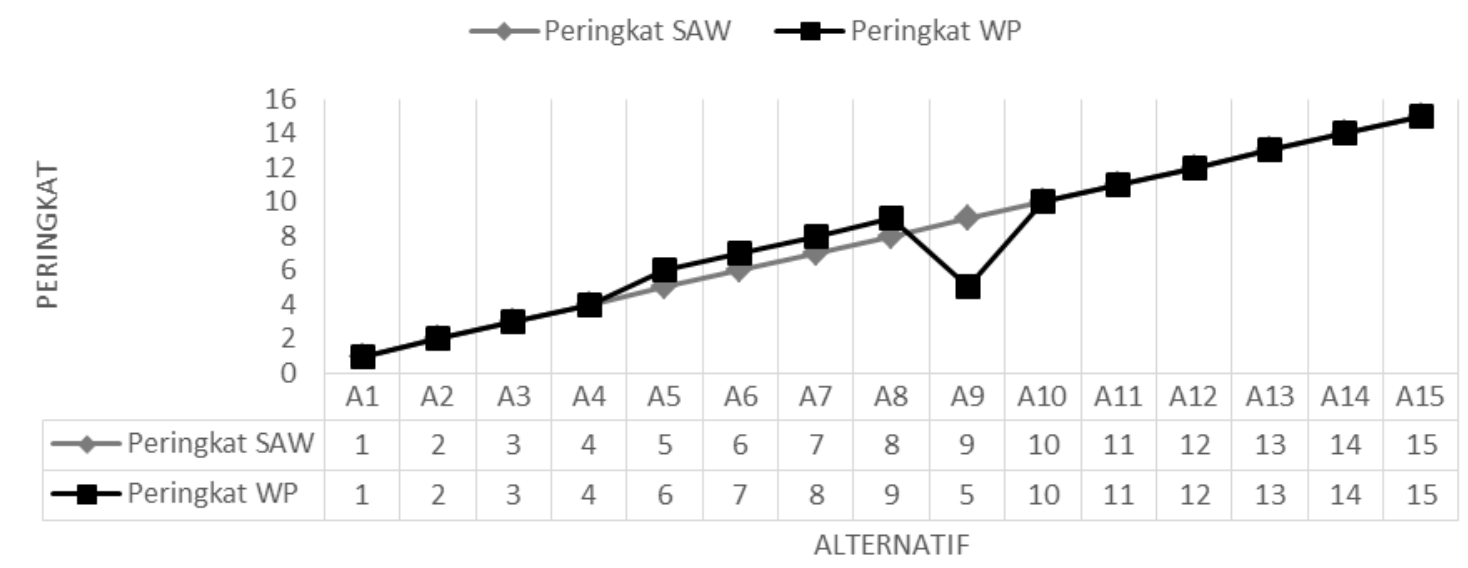

Gambar 7. Hasil SAW dan WP Berdasarkan Peringkat

\subsection{Analisis Perbandingan SAW dan WP Menggunakan RSD}

Berdasarkan hasil perhitungan dengan menggunakan metode SAW dan WP yang telah dilakukan dengan menggunakan 15 data uji seperti terlihat pada Gambar 7, selanjutnya hasil tersebut diujikan dengan menggunakan Relative Standard Deviation (RSD), seperti terlihat pada Tabel 5. Untuk lebih detailnya dapat dilihat pada Gambar 8.

Tabel 5. Hasil RSD SAW dan WP

\begin{tabular}{cc}
\hline Metode & RSD \\
\hline \hline SAW & 10.9901 \\
\hline WP & 8.2004 \\
\hline
\end{tabular}




\begin{tabular}{|c|c|c|c|c|c|}
\hline \multicolumn{6}{|c|}{ SAW (Simple Additive Weighting) } \\
\hline No & NIM & $\begin{array}{r}\text { Nama } \\
\end{array}$ & Nilai & $\mathbf{x}$ & $(X-R)^{2}$ \\
\hline 1 & 14121003 & Nurul Auliah & 12.90 & 1.1067 & 1.2247 \\
\hline 2 & 14121022 & Ricky Arif Sukoco & 12.90 & 1.1067 & 1.2247 \\
\hline 3 & 14121024 & Eko Darma Satrio & 12.90 & 1.1067 & 1.2247 \\
\hline 4 & 14121021 & Adi Sudewo & 12.90 & 1.1067 & 1.2247 \\
\hline 5 & 14121025 & Alfiatun Suhada & 12.40 & 0.6067 & 0.3680 \\
\hline 6 & 14121045 & Faizal Syahr Qomarudin & 12.40 & 0.6067 & 0.3680 \\
\hline 7 & 14121026 & Zidni Karimatan Nisa' & 11.90 & 0.1067 & 0.0114 \\
\hline 8 & 14121017 & Rahmat Dwi Saputra & 11.90 & 0.1067 & 0.0114 \\
\hline 9 & 14121012 & Jefrei Labudo & 11.70 & -0.0933 & 0.0087 \\
\hline 10 & 14121001 & Andi Hidayatullah & 11.50 & -0.2933 & 0.0860 \\
\hline 11 & 14121010 & Rahardian Pamungkas Dupa & 11.40 & -0.3933 & 0.1547 \\
\hline 12 & 14121023 & Joko Purnomo & 11.40 & -0.3933 & 0.1547 \\
\hline 13 & 14121005 & Erwin Febrian & 10.90 & -0.8933 & 0.7980 \\
\hline 14 & 14121049 & Adrianus Nola Pali & 9.90 & -1.8933 & 3.5847 \\
\hline 15 & 14121004 & Adito Efri & 9.90 & -1.8933 & 3.5847 \\
\hline \multicolumn{6}{|c|}{ Rata-Rata } \\
\hline \multicolumn{6}{|c|}{ Jumlah XR 14.0293} \\
\hline \multicolumn{5}{|r|}{ Varian } & 0.9353 \\
\hline \multicolumn{5}{|r|}{ Sigma } & 0.9671 \\
\hline \multicolumn{5}{|r|}{ RSD } & 8.2004 \\
\hline
\end{tabular}

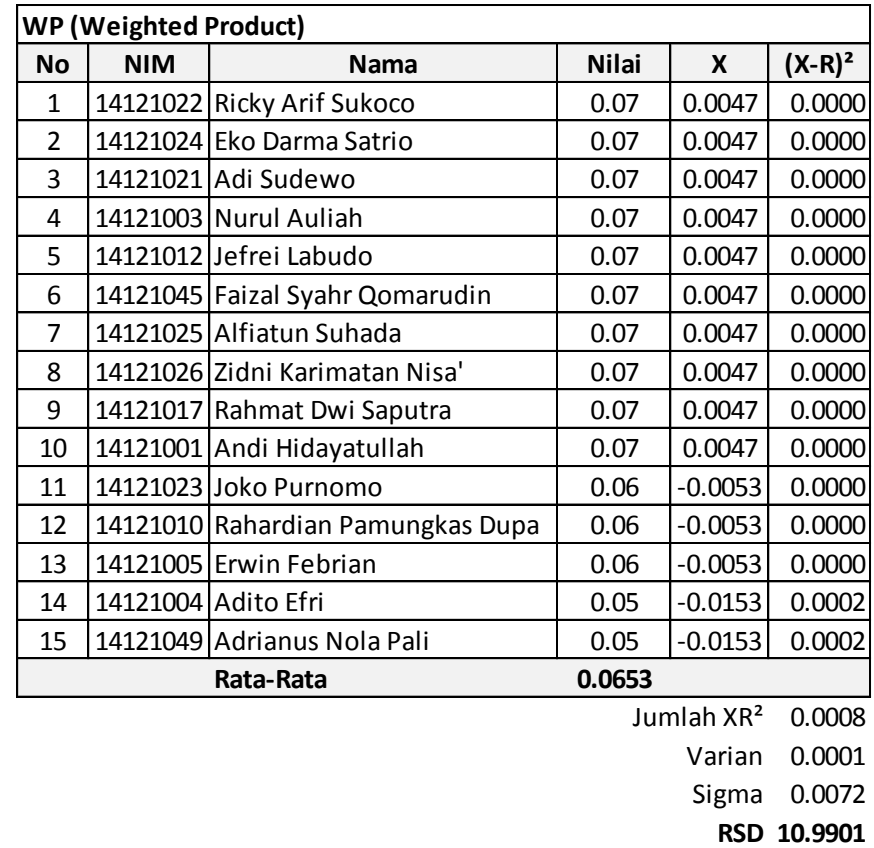

Gambar 8. Perhitungan RSD Metode SAW dan WP

Berdasarkan tabel 5 tersebut, dihasilkan nilai sebesar 8.20\% untuk SAW dan 10.99\% untuk WP. Dalam hal ini semakin tinggi nilai dari RSD, maka perhitungan dengan metode yang dihasilkan semakin optimal. Sehingga berdasarkan pengujian dengan RSD dalam kasus ini, dapat disimpulkan bahwa metode WP lebih optimal dari SAW.

\subsection{Analisis Perbandingan SAW dan WP Berdasarkan Waktu Eksekusi}

Dengan menggunakan data uji yang sama yaitu 15 data uji, hasil pengujian yang telah dilakukan tersebut dapat dilihat pada Gambar 9 untuk pengujian SAW dan Gambar 10 untuk pengujian WP.

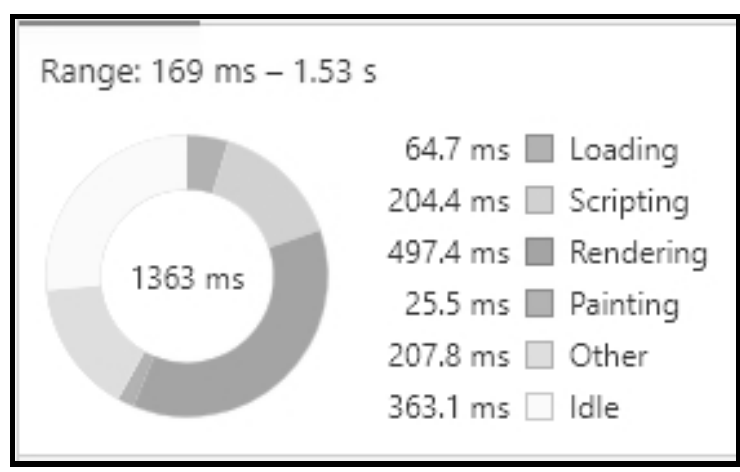

Gambar 9. Pengujian Waktu SAW

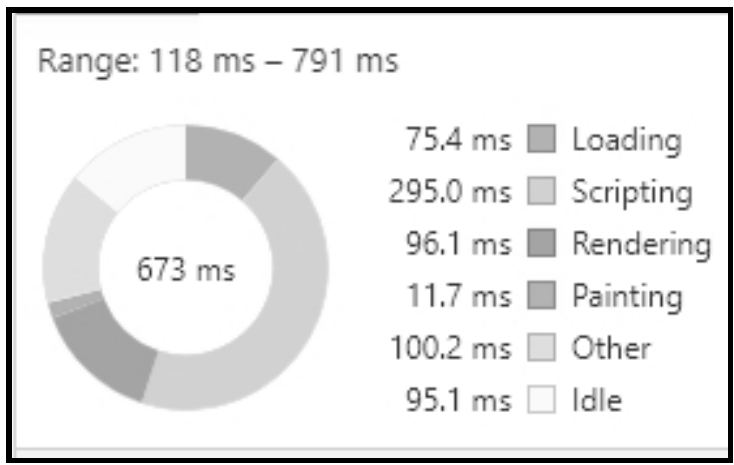

Gambar 10. Pengujian Waktu WP
Berdasarkan Gambar 9 dan 10, untuk lebih jelas perbedaan waktu eksekusi dapat dilihat pada Tabel 6 . Sedangkan performa secara keseluruhan dapat dilihat pada Gambar 12.

Tabel 6. Waktu Eksekusi SAW dan WP

\begin{tabular}{lrr}
\hline \multicolumn{1}{c}{ Kategori } & SAW (ms) & WP (ms) \\
\hline \hline Loading & 64.7 & 75.4 \\
\hline Scripting & 204.4 & 295.0 \\
\hline Rendering & 497.4 & 96.1 \\
\hline Painting & 25.5 & 11.7 \\
\hline Other & 207.8 & 100.2 \\
\hline Idle & 363.1 & 95.1 \\
\hline
\end{tabular}

\section{Keseluruhan Performa SAW dan WP}

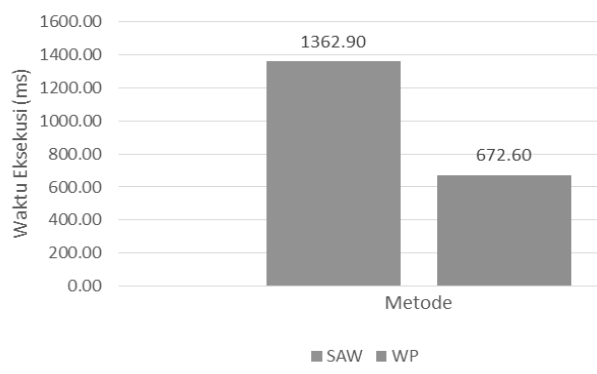

Gambar 11. Performa SAW dan WP 
Berdasarkan Gambar 12, secara keseluruhan performa dari SAW sebesar $1362.90 \mathrm{~ms}$ dan WP sebesar $672.60 \mathrm{~ms}$, sehingga dapat pada kasus ini dapat disimpulkan bahwa WP lebih optimal dari SAW.

\section{KESIMPULAN}

Sistem yang dihasilkan dapat digunakan untuk pemilihan mahasiswa terbaik secara otomatis, sehingga perhitungan dapat dilakukan secara optimal. Hasil Uji terhadap kecepatan waktu akses diperoleh nilai sebesar $1362.90 \mathrm{~ms}$ untuk SAW dan $672.60 \mathrm{~ms}$ untuk WP. Sehingga dalam hal ini metode WP lebih direkomendasikan karena lebih optimal. Sedangkan hasil pengujian menggunakan RSD diperoleh nilai sebesar $8.20 \%$ untuk SAW dan $10.99 \%$ untuk WP. Semakin tinggi nilai dari RSD maka perhitungan dengan metode tersebut lebih optimal. Sehingga dalam hal ini penggunaan metode WP lebih direkomendasikan karena lebih optimal.

\section{SARAN}

Dapat uji cobakan dengan metode yang lain, sebagai bahan perbandingan guna mendapatkan hasil yang lebih optimal. Dalam penentuan nilai bobot W, agar lebih optimal, dapat digunakan metode AHP. Kriteria penilaian dapat ditambahkan atau disesuaikan dengan proses bisnis penolong lain seperlunya untuk memperjelas dan mempersingkat uraian yang harus diberikan.

\section{DAFTAR PUSTAKA}

Bajandoh, F. H. \& Hidayati, R., 2018. Sistem Pendukung Keputusan Untuk Menentukan Siswa Lulusan Terbaik Dengan Menggunakan Promethee (Studi Kasus SMA Negeri 3 Pontianak). Jurnal Coding, Vol. 06, No. 03 (2018), pp. 227-236.

Kusrini, 2007. Konsep dan Aplikasi Sistem Pendukung Keputusan. Yogyakarta: Andi.

Kusumadewi, S., Hartati, S., Harjoko, A. \& Wardoyo, R., 2006. Fuzzy Multi- Atribute Decision Making (Fuzzy MADM). Yogyakarta: Graha Ilmu.

Lailiyah, S., Salmon \& Haeda, N., 2016. Sistem Pendukung Keputusan Menentukan Anak Asuh Pena Prestasi Menggunakan Metode Saw (Simple Additive
Weighting) Pada Lembaga Amil Zakat Dana Peduli Ummat Kalimantan Timur. Sebatik, 15(1), pp. 25-30.

Rini, P. P., Dedi \& Riyanti, N., 2015. Sistem Pendukung Keputusan Pemilihan Dosen Terbaik Berbasis Web Dengan Metode SAW (Simple Additive Weighting) (Studi Kasus: STMIK Global Tangerang). Jurnal SISFOTEK Global, Vol. 5, No. 2, September 2015, ISSN : 2088 - 1762, pp. 100-108.

Savitha, K. \& Chandrasekar, C., 2011. Vertical Handover decision schemes using SAW and WPM for Network selection in Heterogeneous Wireless Networks. Global Journal of Computer Science and Technology, Vol. 11 No. 9, Version 1.0 May 2011, ISSN : 0975-4172, Print ISSN: 0975-4350, 11(9), pp. 18-24.

Septian, M. R. N. \& Purnomo, A. S., 2017. Sistem Penilaian Pegawai Menggunakan Metode Fuzzy Multiple Attribute Decision Making (FMADM) dan Weighted Product (WP). Jurnal Multimedia \& Artificial Intelligence (JMAI), Vol. 1, No. 1, ISSN : 2580-2593, 1(1), pp. 27-33.

Setyawan, A., Arini, F. Y. \& Akhlis, I., 2017. Comparative Analysis of Simple Additive Weighting Method and Weighted Product Method to New Employee Recruitment Decision Support System (DSS) at PT. Warta Media Nusantara. Scientific Journal of Informatics, Vol. 4, No. 1, May 2017, eISSN : 2460-0040, p-ISSN : 2407-7658, pp. 34-42.

Sugiyono, 2014. Metode Penelitian Kuantitatif, Kualitatif, dan $R \& D$. Bandung: Alfabeta.

Turban, E., Aronson, J. E. \& Liang, T. P., 2005. Decision Support Systems and Intelligent Systems (Sistem Pendukung Keputusan dan Sistem Cerdas), Edisi 7. Jilid 1. Yogyakarta: Andi Offset.

Wijaya, A. H. \& Mustafidah, H., 2015. Sistem Pendukung Keputusan Untuk Menentukan Lulusan Mahasiswa Terbaik Dengan Menggunakan Metode Simple Additive Weighting (SAW) Di Fakultas Teknik Universitas Muhammadiyah Purwokerto. Purwokerto, s.n.

Yoni, D. C. \& Mustafidah, H., 2016. Penerapan Metode WP (Weighted Product) Untuk Pemilihan Mahasiswa Lulusan Terbaik Di Fakultas Teknik Universitas Muhammadiyah Purwokerto. JUITA, Vol. IV, No. 1, Mei 2016, ISSN:2086-9398, IV(1), pp. 22-27. 